\title{
Zooplankton response to a warmer northern Wadden Sea
}

\author{
Peter Martens · Justus E. E. van Beusekom
}

Received: 3 October 2007 / Revised: 5 December 2007 / Accepted: 6 December 2007 / Published online: 1 February 2008

(C) Springer-Verlag and AWI 2008

\begin{abstract}
Weekly measurements of mesozooplankton $(>76 \mu \mathrm{m})$ and hydrographic parameters have been carried out since 1984 in the List Tidal Basin (northern Wadden Sea). Monthly water temperature significantly increased by $0.04^{\circ} \mathrm{C}$ year $^{-1}$. The largest increase by $3^{\circ} \mathrm{C}$ in 22 years occurred in September, implying an extension of the warm summer period. Mean annual copepod abundance and length of copepod season correlated significantly with mean temperature from January to May. Except for an increasing Acartia sp. abundance during spring (April-May), no longterm trends in copepod abundance were observed. The percentage of carnivorous zooplankton increased significantly since 1984 mainly due to a sudden increase in the cyclopoid copepod Oithona similis in 1997. We expect that global warming will lead to a longer copepod season and higher copepod abundances in the northern Wadden Sea.
\end{abstract}

Keywords Zooplankton - Copepods - Temperature · Oithona $\cdot$ Wadden Sea $\cdot$ Long-term change

\section{Introduction}

Given the importance of copepods as a food source for higher trophic levels and as a potential controlling factor of phytoplankton blooms it is important to know how this pivotal component of the pelagic ecosystem will respond to climate change and rising temperatures. Copepod abundance and diversity in the northeast Atlantic and in the North Sea is subject to large

Communicated by: J. van Beusekom and K. Reise.

P. Martens $(\varangle)$ · J. E. E. van Beusekom

Alfred-Wegener-Institute for Polar and Marine Research,

Wadden Sea Station Sylt Hafenstrasse 43,

25992 List/Sylt, Germany

e-mail: Peter.Martens@awi.de interannual changes. Since 1948, a downward trend in abundance reversed during the early 1980s (Colebrook et al. 1984) and stabilized during the 1990s (Edwards et al. 2002). Several studies (e.g. Edwards et al. 2001; Reid et al. 2003a) linked changes in the plankton community of the North Sea and the Northwest European shelf to physical changes like the amount of Atlantic inflow or changes in the temperature regime. Beaugrand (2004) suggested that a shift in oceanic biogeographical boundaries along the European continental shelf was responsible for the observed changes in the plankton community. Edwards et al. (2002) and Beaugrand (2003) associated changes in the plankton community to exceptional hydro-climatic events. Richardson and Schoeman (2004) found a bottom-up control of herbivorous and carnivorous zooplankton dynamics in the northeast Atlantic and adjacent shelf. Phytoplankton abundance was positively related to sea-surface temperature at high latitudes where turbulent mixing and high nutrient concentrations prevail and negatively related to seasurface temperatures at low latitudes where stratified conditions prevail. Changes in the phytoplankton and zooplankton may have important consequences for the entire ecosystem: Aebischer et al. (1990) suggested that changes in the plankton community (phytoplankton and zooplankton) propagated up in the food web across four trophic levels.

Most of the above information on long-term change in the zooplankton community is based on the continuous plankton recorder surveys (CPRS, e.g. Reid et al. 2003b). The CPRS uses a plankton recorder towed behind commercial ships. These plankton recorders are known to underestimate zooplankton abundance (Batten et al. 2003; Clark et al. 2001; John et al. 2001) and this may bias the observed trends. Pitois and Fox (2006) recalculated the CPRS data based on comparisons with vertical net hauls (Clark et al. 2001; John et al. 2001). Using species-specific correction factors, they reassessed biomass distribution and long-term 
trends in the North Sea. Pitois and Fox (2006) showed that the zooplankton biomass in the northern North Sea is lower than in the southern North Sea. They observed maximum biomass in the southeastern North Sea that was dominated by smaller copepods. A trend analysis indicated a decreasing trend in zooplankton biomass from 1960 to 2001.

The CPRS is not sampling shallow water. Therefore, little is known on long-term zooplankton trends in the shallow parts of the North Sea. Here we present data from a zooplankton time series started in 1984 in the List Tidal Basin lying in the northern Wadden Sea adjoining the southeastern North Sea. Nutrient and phytoplankton data suggest a general decrease in the eutrophication status and summer phytoplankton biomass (van Beusekom et al. 2005; van Beusekom et al. 2008). In addition, the offshore zooplankton populations show a general decrease in biomass (Greve et al. 2004; Pitois and Fox 2006). Given the bottom-up control found in the East Atlantic and adjacent shelf by Richardson and Schoeman (2004) we expected a decreasing trend in zooplankton biomass in the List Tidal Basin. We will show that in contrast to these expectations, (1) annual zooplankton abundance is not decreasing and (2) that higher winter and spring temperatures may lead to higher annual zooplankton abundances.

\section{Materials and methods}

Area description

The study was conducted in the List Tidal Basin $\left(54^{\circ} 50^{\prime}-55^{\circ} 10^{\prime} \mathrm{N}\right.$ and $\left.8^{\circ} 20^{\prime}-8^{\circ} 40^{\prime} \mathrm{E}\right)$, a $404 \mathrm{~km}^{2}$ semi- enclosed bight in the northern Wadden Sea (North Sea, Europe). A single tidal inlet connects the basin to the open North Sea (Fig. 1). To the north and to the south two dams connecting the Island of Røm $\varnothing$ and the Island of Sylt to the mainland close the basin laterally. Water volume at mean tidal level is about $845 \times 10^{6} \mathrm{~m}^{3}$. The mean water depth is $2.7 \mathrm{~m}$ (Loebl et al. 2007) but reaches up to $40 \mathrm{~m}$ in the main tidal channel. The water column is homogeneously mixed most of the time (Hickel 1980). Tides are semidiurnal and mean tidal range is about $2 \mathrm{~m}$. During low tide, about $30 \%$ of the area is emerged. Monthly mean salinity and temperature reach seasonal minimum values around February and maximum values around August. Monthly mean salinity (1984-2005) ranges between 24.8 and 31.8 in February (mean: $28.1 \pm 1.5$ ) and between 28.6 and 33.4 in August (mean: $30.7 \pm 1.1$ ). Monthly mean temperature (1984-2005) ranges between -1.8 and +5.3 in February (mean: $2.3 \pm 2.0$ ) and between 16.3 and 21.9 in August (mean: $18.4 \pm 1.4$ ). Suspended matter ranges between 20 and $60 \mathrm{mg} / \mathrm{l}$ in winter to $\sim 5 \mathrm{mg} / \mathrm{l}$ in later summer. Gätje and Reise (1998) give a detailed description of the area.

\section{Sampling}

Since 1984, measurements on zooplankton and temperature have been conducted regularly at a fixed station $\left(55^{\circ} 01.30^{\prime} \mathrm{N}, 08^{\circ} 27.10^{\prime} \mathrm{E}\right)$ in the southernmost of three main tidal channels. In general, samples were taken twice a week depending on weather conditions. Mesozooplankton was sampled by taking 351 seawater by bucket from the surface and sieving through a $76 \mu \mathrm{m}$ net. High seston loads
Fig. 1 Map of the List Tidal Basin (situated in the south eastern North Sea). Indicated in the detailed map are the position of the sampling station, the extent of the tidal flats (hatched area) and the $5 \mathrm{~m}$ depth line (stippled line)

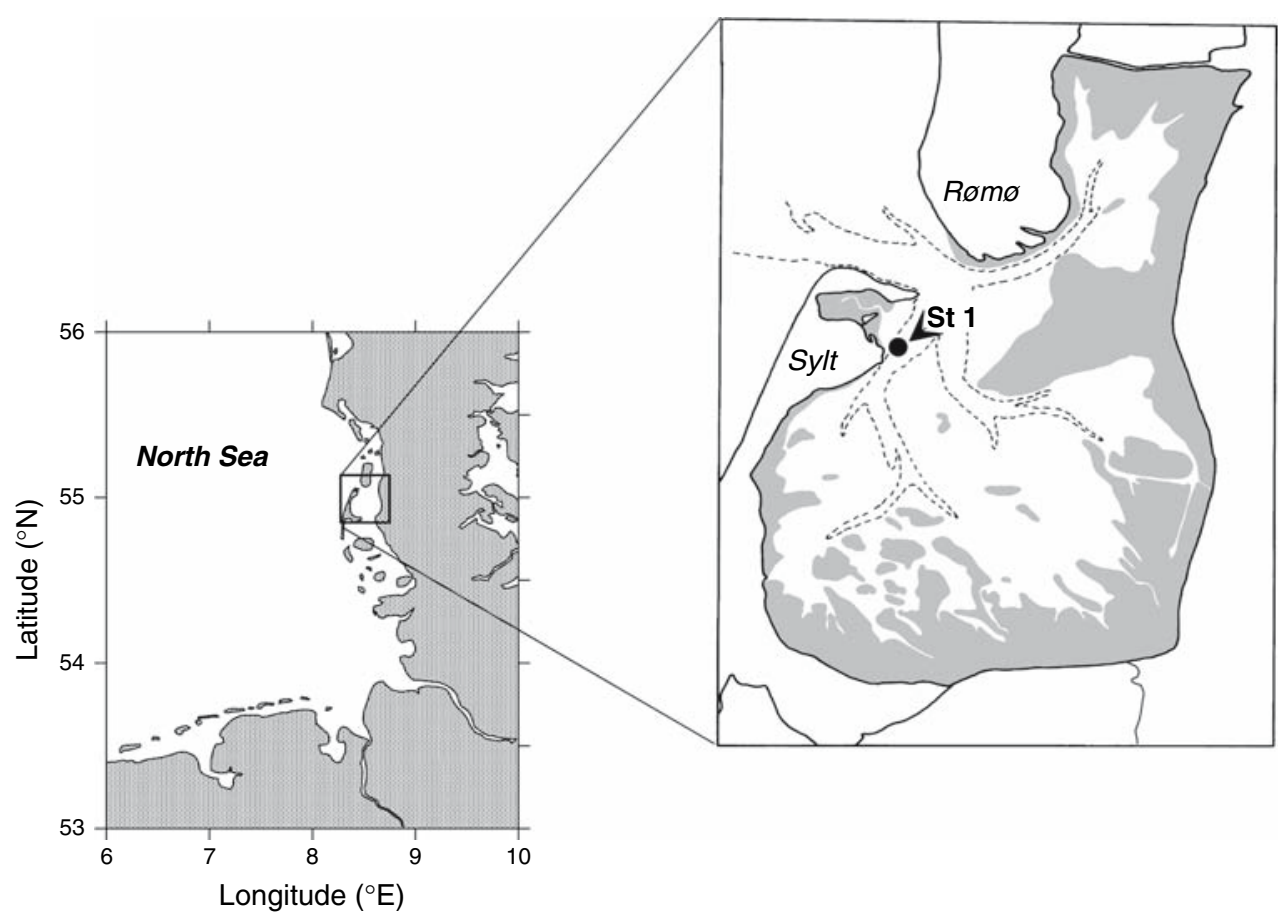


Table 1 Dry weight and feeding habit of zooplankton species in the List Tidal Basin (Martens 1975)

\begin{tabular}{|c|c|c|c|}
\hline Species & Dry weight $(\mu \mathrm{g})$ & Herbivorous & Carnivorous \\
\hline Nauplii Centropages hamatus & 0.11 & $\mathrm{X}$ & \\
\hline Nauplii Temora longicornis & 0.11 & $\mathrm{X}$ & \\
\hline Nauplii Acartia sp. & 0.11 & $\mathrm{X}$ & \\
\hline Nauplii Oithona sp. & 0.11 & $X$ & \\
\hline Nauplii Para- and Pseudocalanus sp. & 0.11 & $X$ & \\
\hline Nauplii Balanidae & 4.50 & $\mathrm{X}$ & \\
\hline Cypris larvae Balanidae & 16.00 & $X$ & \\
\hline Copepodit Centropages hamatus & 2.00 & $\mathrm{X}$ & \\
\hline Copepodit Temora longicornis & 2.50 & $\mathrm{X}$ & \\
\hline Copepodit Acartia sp. & 1.00 & $\mathrm{X}$ & \\
\hline Copepodit Oithona sp. & 0.80 & $\mathrm{X}$ & \\
\hline Copepodit Para- and Pseudocalanus sp. & 1.20 & $\mathrm{X}$ & \\
\hline Centropages hamatus adult & 15.70 & $\mathrm{X}$ & \\
\hline Temora longicornis adult & 18.40 & $\mathrm{X}$ & \\
\hline Acartia sp. adult & 6.40 & $\mathrm{X}$ & \\
\hline Oithona similis adult & 3.00 & & $\mathrm{X}$ \\
\hline Paracalanus parvus adult & 5.10 & $\mathrm{X}$ & \\
\hline Pseudocalanus elongatus adult & 14.00 & $\mathrm{X}$ & \\
\hline Harpacticoidea (larvae and adult) & 0.80 & $\mathrm{X}$ & \\
\hline Noctiluca scintillans & 0.08 & $\mathrm{X}$ & \\
\hline Oikopleura dioica & 10.00 & $\mathrm{X}$ & \\
\hline Larvae of Bivalvia & 0.08 & $\mathrm{X}$ & \\
\hline Larvae of Gastropoda & 2.00 & $\mathrm{X}$ & \\
\hline Trochophora larvae & 0.15 & $\mathrm{X}$ & \\
\hline Metratrochophota of Spionidae & 0.50 & $\mathrm{X}$ & \\
\hline Metratrochophora of other Polychaeta & 0.50 & $\mathrm{X}$ & \\
\hline Nektochaeta of Spionidae & 10.60 & $\mathrm{X}$ & \\
\hline Nektochaeta of other Polychaeta & 10.60 & $\mathrm{X}$ & \\
\hline Lanice conchilega & 12.00 & $\mathrm{X}$ & \\
\hline Magelone papilicornis & 5.00 & $\mathrm{X}$ & \\
\hline Ophioplutei & 1.20 & $\mathrm{X}$ & \\
\hline Echinoplutei & 10.00 & $\mathrm{X}$ & \\
\hline Bipinnaria larvae & 10.00 & $\mathrm{X}$ & \\
\hline Larvae of Membranipora sp. & 1.00 & $\mathrm{X}$ & \\
\hline Rotatoria & 0.07 & $X$ & \\
\hline Alaurina composite & 2.00 & & $\mathrm{X}$ \\
\hline Sagitta sp. & 10.00 per mm & & $X$ \\
\hline Podon sp. & 8.00 & & $\mathrm{X}$ \\
\hline Evadne sp. & 3.00 & & $\mathrm{X}$ \\
\hline Zoea larvae & 20.00 & & $\mathrm{X}$ \\
\hline Megalopa larvae & 50.00 & & $\mathrm{X}$ \\
\hline Rathkea oktopunctata & 14.30 & & $\mathrm{X}$ \\
\hline Sarsia tubulosa & 14.00 & & $\mathrm{X}$ \\
\hline Pleurobrachia pileus & 16.00 & & $\mathrm{X}$ \\
\hline Obelia geniculata & 15.20 & & $\mathrm{X}$ \\
\hline
\end{tabular}

of the water prevented the use of plankton nets due to clogging. The samples were preserved in $2 \%$ formaldehyde-seawater solution and counted under the microscope.
Zooplankton dry weight was computed after Martens (1975; Table 1). The water temperature was measured with a reversing thermometer attached to a TPN water sampler 
(Transparent Plastic Nansen Water Sampler, System Hydrobios) or a Niskin-type water sampler. Strong turbulence prevents stratification in these waters (Hickel 1980). As part of these time series, water samples were also analyzed for hydrographic parameters (salinity, suspended mater, $\mathrm{pH}$ ), nutrients and phytoplankton biomass (chlorophyll $a$ ). Details are given by van Beusekom et al. (2008) and Loebl et al. (2008).

We summarized the primary data to monthly mean values and calculated anomalies as the difference between the actual monthly value and the mean monthly value for the entire period of investigation (1984-2005). We tested for significant correlations with Pearson's regression analysis if the data were normally distributed (Shapiro-Wilk's $W$ test) and otherwise we used the Spearman's Rank correlation coefficient (SR) [StatSoft, Inc. 2004. STATISTICA für Windows (Software-System für Datenanalyse) Version 6].

\section{Results}

\section{Temperature}

Monthly mean water temperature (Fig. 2a) shows a clear seasonal cycle with maximum values in August (mean of 1984-2005: $18.4^{\circ} \mathrm{C}$ ) and minimum values in February (mean of 1984-2005: $2.3^{\circ} \mathrm{C}$ ). Temperature anomaly (deviation from the mean monthly values 1984-2005) shows strong interannual variation (Fig. 2b). The conspicuous features are the cold winters of 1984-1987 and 1996, the warm winters 1988-1994 and 1999-2002, the relatively cold late summer (August-September) values until 1988 and the warm late summer values from 1995 onward. The monthly temperature anomalies are normally distributed (Shapiro-Wilk's $W$ test) and correlate significantly with time $(P<0.002)$. The linear regression coefficient suggests a mean increase of about $0.04^{\circ} \mathrm{C}_{\text {year }}{ }^{-1}$. However, the amount of variability explained by time is low and indicates high interannual variability in temperature anomalies and a minor long-term trend. A Spearman rank correlation for each month separately was only significant for September with a temperature increase of almost $3^{\circ} \mathrm{C}$ from values around $13-14^{\circ} \mathrm{C}$ during the early $1980 \mathrm{~s}$ to $14.5-17.5^{\circ} \mathrm{C}$ during the early 2000s (Fig. 3). September temperatures are normally distributed and a Pearson's correlation is significant $(P<0.001)$ with a linear trend of $0.13^{\circ} \mathrm{C}_{\text {year }}{ }^{-1}$. Based on this we conclude that during the past 22 years the warm summer period was extended by about 1 month.

\section{Copepod dynamics}

Monthly mean copepod numbers show large interannual differences (Fig. 4). Low spring densities indicate a late start of the growing season and prevail after cold winters (e.g. 1984-1987, 1996, 2001). Centropages hamatus and Acartia sp. are dominating copepods making up $75 \pm 5 \%$ of total adult copepod numbers. The calanoid copepod Acartia sp. (Fig. 5a) shows a similar pattern as total copepods with low spring abundances and a late start of the growing season after cold winters. C. hamatus is an important holoplanktonic herbivorous species occurring from May/June until September but with strong interannual variations (Fig. 5b). Note again the low densities after cold winters (e.g. 1984-1987, 1996, 2001).

Figures 4 and 5 suggest that the copepod season tends to be shorter and that the seasonal development tends to start later in years with cold winters. We tested the influence of temperature on mean annual numbers with a correlation analysis using the mean winter and spring temperature as the independent variable (January-May). As mean annual
Fig. 2 Contour plot of monthly mean water temperature $\left({ }^{\circ} \mathrm{C}\right)$ (left) and monthly water temperature anomaly (deviation from the mean monthly temperature $\left({ }^{\circ} \mathrm{C}\right)$ (right) in the List Tidal Basin from 1984 until 2005

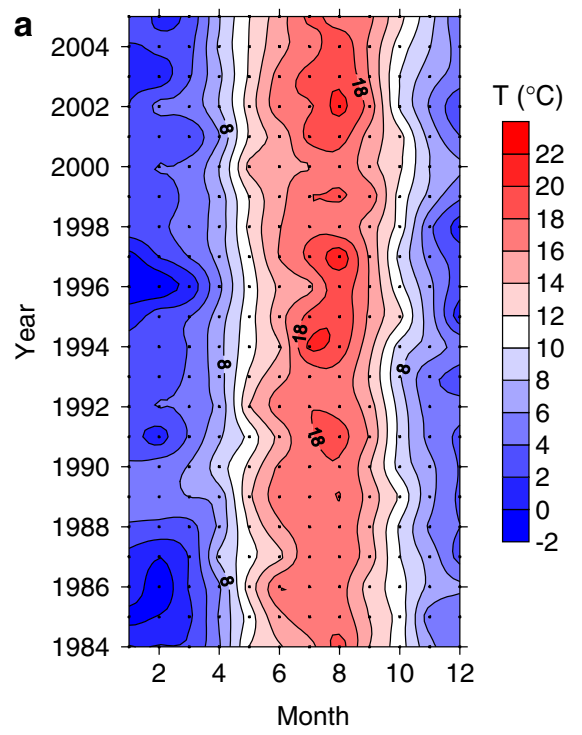




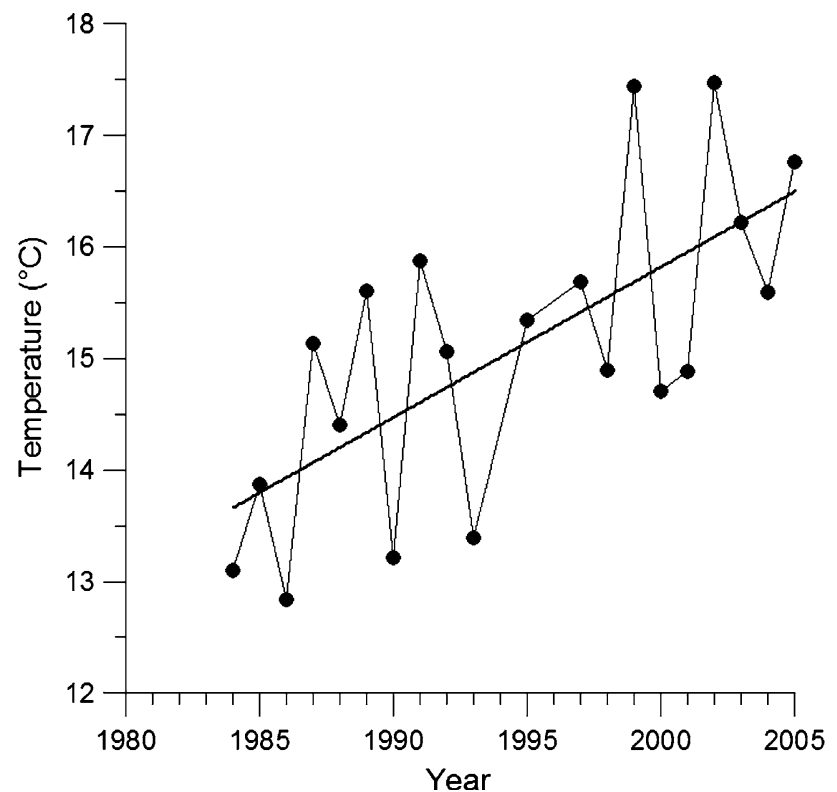

Fig. 3 Increase of water temperature in September in the List Tidal Basin $\left(R^{2}=0.46 ; N=20 ; P<0.001\right.$; Data are normally distributed). The annual increase is $0.134^{\circ} \mathrm{C}$ year $^{-1}$

Acartia and C. hamatus numbers were not normally distributed, we used Spearman's rank correlation. Mean annual copepod numbers were normally distributed and here we calculated Pearson's correlation coefficients. In all cases, we found a significant correlation with mean winter and spring temperature (Table 2). Mean winter and spring temperatures explained about $40 \%$ of the interannual variance in total copepod numbers (Fig. 6).

We estimated the length of the copepod season by counting the number of months with abundances larger than

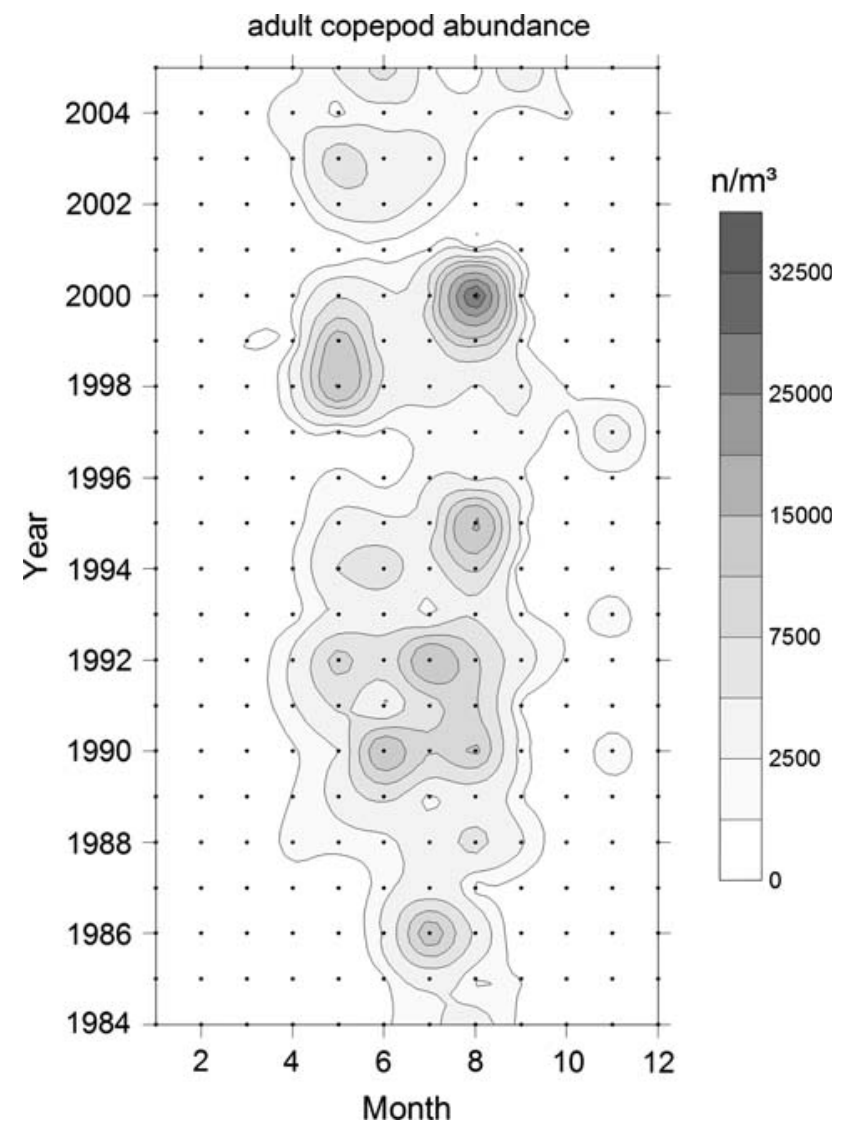

Fig. 4 Contour plot of monthly mean adult total copepod numbers $\left(\mathrm{n} \mathrm{m}^{-3}\right)$ in the List Tidal Basin from 1984-2005

$1,000 \mathrm{~m}^{-3}$ for total copepods and Acartia sp. and with abundances larger than $500 \mathrm{~m}^{-3}$ for $C$. hamatus. The season length was normally distributed and a Pearson correlation
Fig. 5 Contour plot of (left) monthly mean adult Acartia sp. numbers $\left(\mathrm{n} \mathrm{m}^{-3}\right)$ and (right) monthly mean adult Centropages hamatus numbers $\left(\mathrm{n} \mathrm{m}^{-3}\right)$ in the List Tidal Basin from 1984-2005

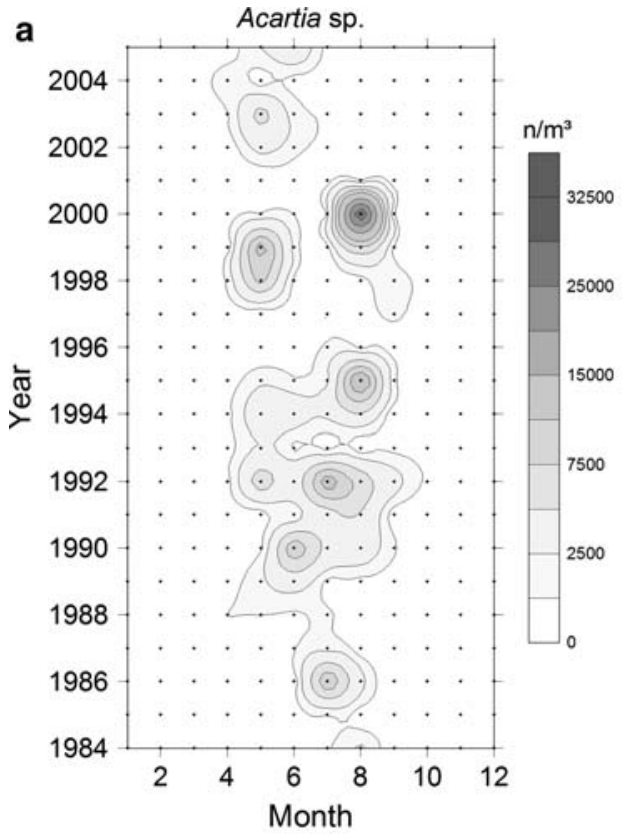


Table 2 Results from the regression analysis between winter and spring temperatures (January-May) and mean annual Acartia sp. numbers and Acartia sp. season length (number of months with abundance $>1,000 \mathrm{~m}^{-3}$ ), mean annual Centropagus hamatus numbers and Centropagus hamatus season length (number of months with abundance $>500 \mathrm{~m}^{-3}$ ) and mean annual total copepod numbers and copepod season length (number of months with abundance > $1,000 \mathrm{~m}^{-3}$ )

\begin{tabular}{llll}
\hline Independent value & Dependent value & Method & Result \\
\hline Temperature & Acartia sp. (mean annual abundance)(season length) & Spearman & $\begin{array}{l}R=0.53 ; N=21 ; P<0.012 \\
R^{2}=0.45 ; N=21 ; P<0.001\end{array}$ \\
& & Pearson & $R=0.61 ; N=21 ; P<0.0034$ \\
Temperature & C. hamatus (mean annual abundance) (season length) & Spearman & not significant $(P=0.41)$ \\
& & Pearson & $R^{2}=0.40 ; N=21 ; \mathrm{p}<0.002$ \\
Temperature & Total copepods (mean annual abundance) (season length) & Pearson & $\mathrm{R}^{2}=0.38 ; N=21 ; P<0.003$
\end{tabular}

Data from 1989 were omitted (no data for April-June). Acartia sp. and Centropagus hamatus represent $75 \pm 5 \%$ of total copepod numbers

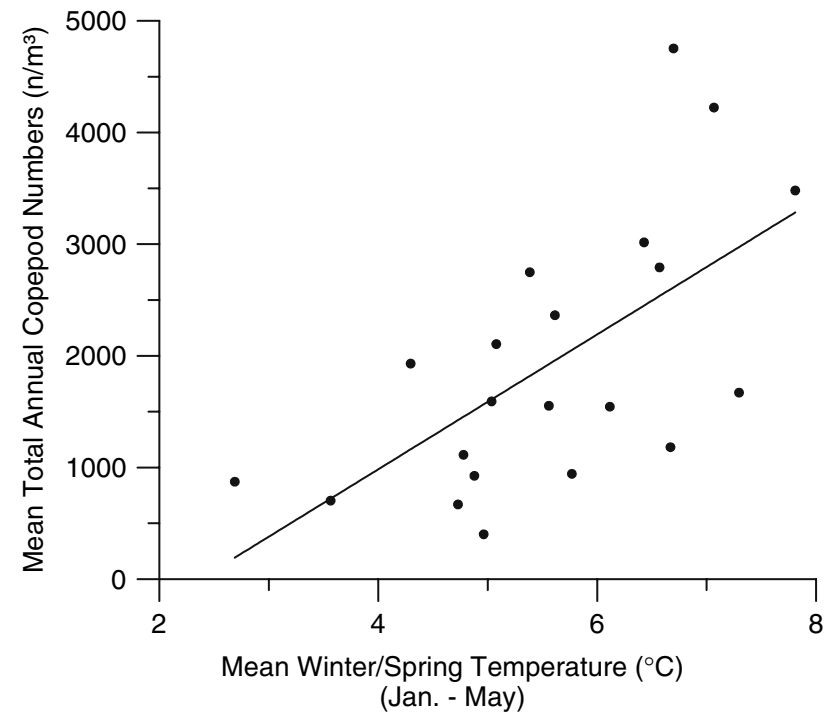

Fig. 6 Correlation between mean winter/spring temperature (January-May) and mean annual copepod numbers $\left(\mathrm{n} \mathrm{m}^{-3}\right)$ in the List Tidal $\operatorname{Basin}\left(R^{2}=0.40 ; N=21 ; P=0.002\right)$

showed a significant influence of winter and spring temperature on the length of the season for total copepods $\left(R^{2}=0.38\right)$ and for Acartia sp. $\left(R^{2}=0.45\right.$; Table 2$)$.

A multiple regression with time and temperature as independent variables revealed no significant temporal trend in total copepod abundance (Temperature January-May: $P<0.0025$; Time: $P<0.66$ ). Also, a simple linear regression showed no significant long-term trend in mean annual copepod numbers $(P<0.93)$. Acartia sp. abundance is on the borderline of not being normally distributed (ShapiroWilk's $W$ test: $P<0.047)$. A Pearson's correlation with the mean temperature (January-May) is significant $(P<0.0055)$ and explains $34 \%$ of the variance of mean annual Acartia abundance. A multiple regression with time and temperature as independent variables showed that no significant trend is present (Temperature January-May: $P<0.0055$; Time: $P<0.51)$. A simple linear regression showed no significant long-term trend in mean annual Acartia numbers $(P<0.90)$. Acartia abundance in spring (April and May)

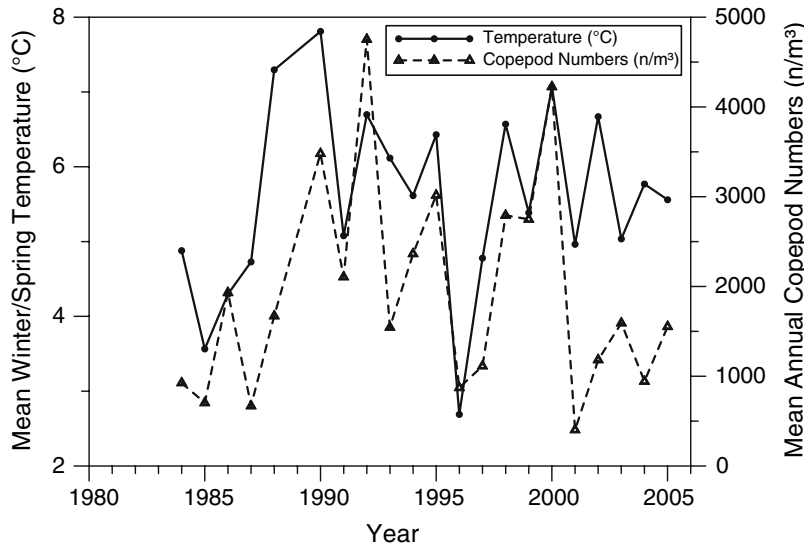

Fig. 7 Mean winter/spring temperature and mean annual total copepod numbers from 1984 until 2005

increased significantly (Spearman rank: $R=0.45, P<0.038$; Fig. 5a).

The impact of cold winters and springs is also evident from a plot of mean winter and spring temperature and total annual copepod numbers against time (Fig. 7). The graph highlights the large interannual differences in winter and spring temperatures of up to $3^{\circ} \mathrm{C}$. These differences are large compared to the annual trend of $0.04^{\circ} \mathrm{C}_{\text {year }}{ }^{-1}$ and suggest that at present any trend due to global warming is overridden by interannual dynamics. It is interesting to note that the mean copepod abundance since 2001 is on a similar level as during the early 1980s despite the much higher winter-spring temperatures indicating the effect of further, yet unidentified process involved in the seasonal copepod dynamics.

The long-term dynamics of $O$. similis (a carnivorous cyclopoid copepod) show low numbers before 1996 and high numbers after 1996 especially during late summer and autumn (Fig. 8). To compare long-term shifts between mainly carnivorous and mainly herbivorous species, the numbers per volume were converted to dry weight to exclude the effect of size differences between the species using factors of Martens (1975) (Table 1). The ratio 


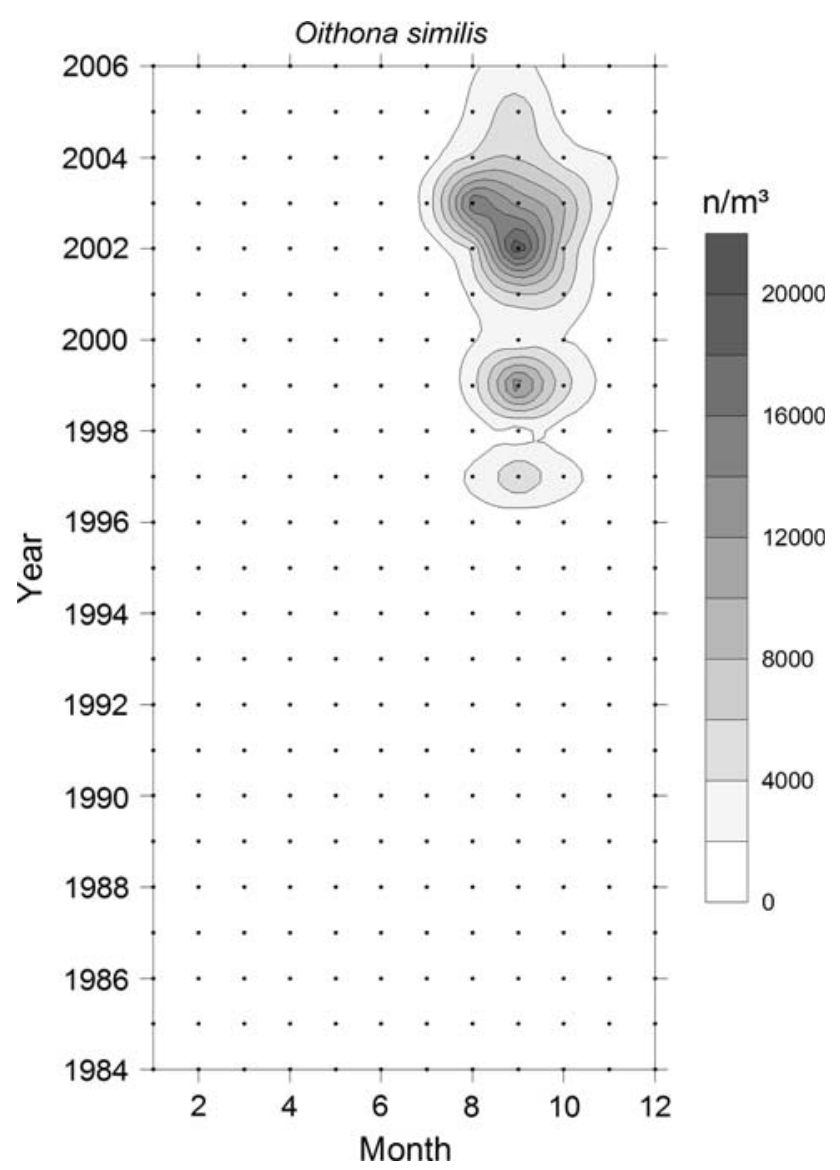

Fig. 8 Contour plot of monthly mean adult Oithona similis abundance $\left(\mathrm{n} \mathrm{m}^{-3}\right)$

between herbivorous and carnivorous mesozooplankton biomass increased significantly from 1984 until 2005 (Spearman's rank; $P<0.0001$; Fig. 9). This is mainly due to the increase of the mainly carnivorous (Lampitt 1978), "ambush feeding" (Svensen and Kiørboe 2000) copepod O. similis.

\section{Discussion}

Temperature increased by $0.04^{\circ} \mathrm{C}_{\text {year }}{ }^{-1}$ during the past 22 years. The trend fits within a global warming trend (IPCC 2007) and within a warming trend in the North Sea and Baltic (van Aken 2003; Wiltshire and Manly 2004; MacKenzie and Schiedek 2007). However, the warming trend is minor compared to the interannual variation in the annual temperature regime. We found a significant effect of warmer winter and spring temperatures on the seasonal development of copepods. Based on this we suggest that global warming will lead to an earlier start of the copepod seasonal development and to a longer season and larger mean annual abundances in the List Tidal Basin.

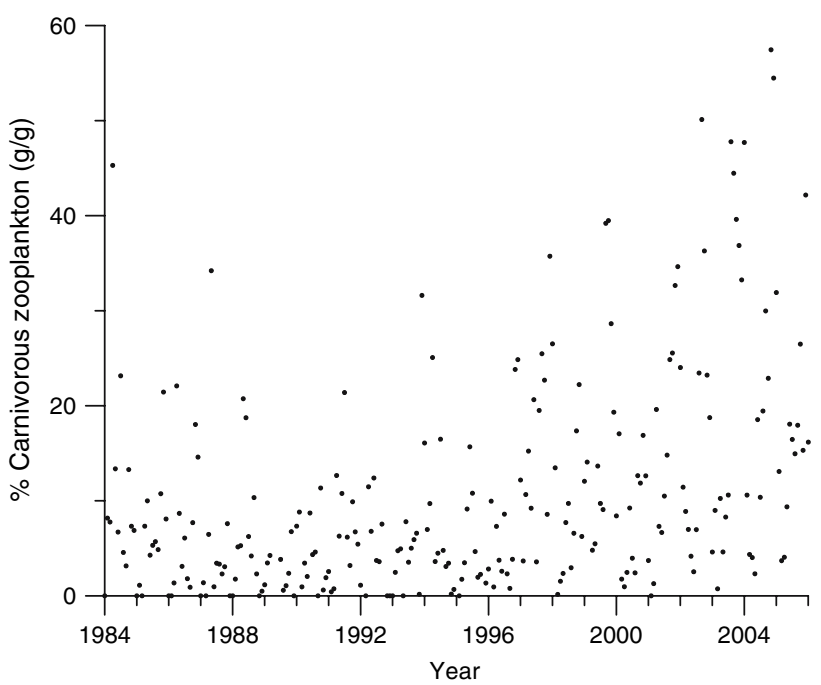

Fig. 9 Increasing percentage of the mainly carnivorous fraction of the whole mesozooplankton in the List Tidal Basin with time. Spearman's rank correlation coefficient: $\mathrm{RS}=+0.405 ; P<0.0001$

Temperature control of interannual copepod dynamics

In contrast to the decreasing trend of copepod numbers in the North Sea (Clark and Frid 2001; Greve et al. 2004; Pitois and Fox 2006) we observed no significant decreasing trend but found that the temperature regime of the preceding winter and spring (January-May) explained $40 \%$ of the interannual variability of the annual mean copepod abundance. During the 22 years of our observations, marked changes have occurred in the seasonal dynamics. Firstly, we observed a progressively earlier seasonal increase in Acartia sp. abundance and secondly we found that the share of carnivorous zooplankton in total zooplankton biomass has gradually increased. The latter increase was largely due to a proliferation of the copepod $O$. similis.

Our analysis further suggests that winter and spring temperatures have a strong impact on zooplankton dynamics in our area. This may be explained by the fact that many of the copepod species in the List Tidal Basin develop from benthic eggs (e.g. Centropagus or Acartia). The effect of temperature on hatching rates is well known (Arendt et al. 2005; Holste and Peck 2006). In addition, the increasing autumn temperatures and an extended growth season (better physiological conditions of females) may have stimulated egg survival.

Food availability seems to be of secondary importance. Although riverine nutrient loads are decreasing and despite a decrease in summer phytoplankton biomass (as chlorophyll; van Beusekom et al. 2005), this did not clearly affect zooplankton abundance. However, a closer look at the winter and spring temperatures and copepod abundance against time shows that during recent years copepod 
numbers are on a similar level as during the 1980s despite much higher temperatures (Fig. 7). Three factors may contribute to this: a recent decline in food availability (a bottom-up effect related to decreased riverine nutrient loads), the proliferation of carnivorous zooplankton or an increased predation by fish larvae and small fish. Further studies are needed to clarify this. For the Wadden Sea no other time series on zooplankton are available but it is interesting to note that Fransz et al. (1992) noted that Temora longicornis biomass increased between 1973 and 1991 in the Western Dutch Wadden Sea (Marsdiep).

The proliferation of the carnivorous copepod $O$. similis contrasts with a general decrease observed in the rest of the North Sea (Pitois and Fox 2006). Apparently, conditions that support the development of this copepod in the List Tidal Basin have improved. We suggest that at least three factors contribute to this. Firstly, nutrient limitation intensified during recent years (Loebl et al. 2008). This may have lead towards a microbial loop dominated plankton community with a large share of ciliates being an important food source for the small carnivorous copepod $O$ similis. Secondly, increased September temperatures enhanced growth conditions. Thirdly, light availability and therefore phytoplankton growth conditions during September have improved (Loebl et al. 2008). The timing of the sudden increase of O. similis (in 1997) is striking as the September temperature increase was more gradual (Fig. 2) but coincides with a possible regime shift in the North Sea around 1997 (Weijerman et al. 2005).

\section{Regime shifts in the North Sea}

According to Beaugrand (2004) the North Sea underwent a dramatic regime shift during 1983-1988. A warm-biological dynamic regime followed a cold-biological regime, ecological processes being strongly dependent on hydroclimatic variability in the northeast Atlantic Ocean (Beaugrand and Ibanez 2004). Weijerman et al. (2005) analysed 28 abiotic and 50 biological time series in the North Sea and Wadden Sea and identified two major shifts around 1979 and 1988 and possibly a third minor shift in 19971998. Our time series are not long enough to identify these shifts with any certainty. However it is interesting to note that two marked changes in interannual copepod dynamics in the List Tidal Basin coincide with these shifts. Firstly, Acartia and total copepod increase started almost one month earlier after 1987. This change is most probably related to the extreme warm winter and spring temperatures in 1988/ 1989 as indicated by the relation between winter and spring temperature and copepod dynamics (Fig. 7; Table 2). The sudden increase of $O$. similis in 1997 coincides with the minor shift proposed by Weijerman et al. (2005). We could not provide a clear explanation for the timing of the sudden
Oithona increase after 1997. Probably, a yet unknown complex change comprising both abiotic and biotic components is involved in the latter shift.

\section{Conclusions}

Temperature has a strong and significant effect on the seasonal development of copepods in the List Tidal Basin with warmer winter and spring temperatures leading to a longer copepod season and higher mean annual abundances. Despite a warming trend since 1984 of $0.04^{\circ} \mathrm{C}$ year $^{-1}$ no significant temporal trends in copepod abundance were observed except for a progressively earlier start of the Acartia sp. season. September temperatures significantly increased $0.13^{\circ} \mathrm{C}_{\text {year }}{ }^{-1}$ since 1984 . Since 1997 , O. similis developed a pronounced autumn bloom. We expect that global warming will lead to a longer copepod season and higher copepod abundances in the northern Wadden Sea.

Acknowledgments We thank captains and crew of the FK "Mya" and Tatyana Romanova for their assistance during sampling. Comments by Karsten Reise, Martina Loebl and an anonymous reviewer greatly improved the manuscript.

\section{References}

Aebischer NJ, Coulson JC, Colebrook JM (1990) Parallel long-term trends across four marine trophic levels and weather. Nature 347:753-755

Arendt KE, Jonasdottir SH, Hansen PJ, Gartner S (2005) Effects of dietary fatty acids on the reproductive success of the calanoid copepod Temora longicornis. Mar Biol 146(3):513-530

Batten SD, Clark R, Flinkman J, Hays G, John E, John AWG, Jonas T, Lindley JA,Stevens DP, WalneA (2003) CPR sampling: the technical background, materials and methods, consistency and comparability. Prog Oceanogr 58:193-215

Beaugrand G (2003) Long-term changes in copepod abundance and diversity in the north-east Atlantic in relation to fluctuations in the hydroclimatic environment. Fish Oceanogr 12:270-283

Beaugrand G (2004) The North Sea regime shift: evidence, causes, mechanisms and consequences. Prog Oceanogr 60:245-262

Beaugrand G, Ibanez F (2004) Monitoring marine plankton ecosystems. II: Long-term changes in North Sea calanoid copepods in relation to hydro-climatic variability. Mar Ecol Prog Ser 284:35-47

Clark RA, Frid CLJ, Batten S (2001) A critical comparison of two long-term zooplankton time series from the central west North Sea. J Plankt Res 23:27-39

Clark RA, Frid CLJ (2001) Long-term trends in the Central-West North Sea. Senckenbergiana Maritima 31(2):117-124

Colebrook JM, Robinson GA, Hunt HG, Roskell J, John AWG, Bottrell HH, Lindley NR, Collins NR, Halliday NC (1984) Short note: Continuous Plankton Records: a possible reversal in the downward trend in the abundance of the plankton of the North Sea and the Northeast Atlantic. J du Conseil Int pour l'Explor de la Mer 41:304-306

Edwards M, Reid P, Planque B (2001) Long-term and regional variability of phytoplankton biomass in the Northeast Atlantic (1960-1995). ICES J Mar Sci 58:39-49 
Edwards M, Beaugrand G, Reid PC, Rowden AA, Jones MB (2002) Ocean climate anomalies and the ecology of the North Sea. Mar Ecol Prog Ser 239:1-10

Fransz HG, Cadée GC, Gonzalez SR, Hansen FC (1992) Long-term change of Temora longicornis (Copepoda, Calanoida) abundance in a Dutch tidal inlet (Marsdiep) in relation to eutrophication. Neth J Sea Res 30:23-32

Gätje C, Reise K (eds) (1998) Ökosystem wattenmeer: Austausch, Transport und Stoffwandlungsprozesse. Springer, Heidelberg

Greve W, Reiners F, Nast J, Hoffmann S (2004) Helgoland Roads meso- and macrozooplankton time-series 1974 to 2004: lessons from 30 years of single spot, high frequency sampling at the only offshore island of the North Sea. Helgol Mar Res 58:274-288

Hickel W (1980) The influence of Elbe River water on the Wadden Sea of sylt (German Bight, North Sea). D Hydrogr Z 33(2):43-52

Holste L, Peck MA (2006) The effects of temperature and salinity on egg production and hatching success of Baltic Acartia tonsa (Copepoda: Calanoida): a laboratory investigation. Mar Biol 148(5):1061-1070

IPCC (2007) Contribution of working group I to the fourth assessment report of the intergovernmental panel on climate change. Summary for policymakers, $18 \mathrm{pp}$

John EH, Batten SD, Harris RP, Hays GC (2001) Comparison between zooplankton data collected by the continuous plankton recorder survey in the English Channel and by WP-2 nets at station L4, Plymouth (UK). J Sea Res 46:223-232

Lampitt RS (1978) Carnivorous feeding by a small marine copepod. Limnol Oceanogr 23(6):1228-1231

Loebl M, Dolch T, van Beusekom JEE (2007) Annual dynamics of pelagic primary production and respiration in a shallow coastal basin. J Sea Res 58:269-282

Loebl M, Colijn F, van Beusekom JEE (2008) Increasing nitrogen limitation during summer in the List Tidal Basin (Northern Wadden Sea). Helgol Mar Res 62. doi:10.1007/s10152-007-0089-0

MacKenzie BR, Schiedek D (2007) Daily ocean monitoring since the 1860 s shows record warming of northern European seas. Global Change Biol 13:1335-1347
Martens P (1975) Über die Qualität und Quantität der Sekundär- und Tertiärproduzenten in einem marinen Flachwasserökosystem der westlichen Ostsee. Diss. Univ. of Kiel, 111 pp

Pitois SG, Fox CJ (2006) Long-term changes in zooplankton biomass concentration and mean size over the Northwest European shelf inferred from Continuous Plankton Recorder data. ICES J Mar Sci 63:785-798

Reid PC, Edwards M, Beaugrand G, Skogen M, Stevens D (2003a) Periodic changes in the zooplankton of the North Sea during the twentieth century linked to oceanic inflow. Fish Oceanogr 12:260-269

Reid PC, Colebrook JM, Matthews JBL, Aiken J (2003b) The continuous plankton recorder: concepts and history, from plankton indicator to undulating recorders. Prog Oceanogr 58:117-173

Richardson AJ, Schoeman DS (2004) Climate impact on plankton ecosystems in the Northeast Atlantic. Science 305:1609-1612

StatSoft (2004) STATISTICA für Windows [Software-System für Datenanalyse] Version 6. http://www.statsoft.com

Svensen C, Kiørboe T (2000) Remote prey detection in Oithona similis: hydromechanical versus chemical cues. J Plankt Res 22(6): 1155-1166

van Aken HM (2003) 140 years of daily observations in a tidal inlet (Marsdiep). ICES Mar Sci Symp 219:359-361

Van Beusekom JEE, Bot PVM, Goebel JHM, Lenhart H, Pätsch J, Peperzak L, Petenati T, Reise K (2005) Eutrophication. In: Essink K, Dettmann C, Farke H, Laursen K, Lüerßen G, Marencic H, Wiersinga W (eds) Wadden Sea Quality Status Report 2004. Wadden Sea Secretariat, Wilhelmshaven, pp 141-154

van Beusekom JEE, Weigelt-Krenz S, Martens P (2008) Long-term dynamics in winter nitrate in the List Tidal Basin. Helg Mar Res 62. doi:10.1007/s10152-007-0092-5

Weijerman M, Lindeboom HJ, Zuur A (2005) Regime shifts in marine ecosystems of the North Sea and Wadden Sea. Mar Ecol Prog Ser 289:21-39

Wiltshire KH, Manly BFJ (2004) The warming trend at Helgoland Roads, North Sea: phytoplankton response. Helgol Mar Res 58:269-273 